\title{
Keragaman Genetik Bulu Babi (Echinoidea)
}

\section{Genetic Diversity of Sea Urchin (Echinoidea)}

\author{
Abdul Hamid A. Toha \\ Jurusan Perikanan FPPK Universitas Negeri Papua \\ $J l$. Gunung Salju Amban Manokwari-Irian Jaya Barat \\ E-mail: hamid.toha@unipa.ac.id, hamid.toha@yahoo.co.id, afisindika@yahoo.com
}

Bulu babi adalah hewan Avertebrata laut yang kaya manfaat. Organisme yang tergolong dalam kelas Echinoidea ini dapat dimanfaatkan sebagai sumber pangan bergizi (Darsono \& Sukarno, 1993; Nontji, 2002), berguna dalam ekologi (Lawrence, 1975; Lang \& Schroeter, 1976), dan bernilai ekonomis penting. Bulu babi juga berfungsi sebagai organisme hiasan dan digunakan dalam bidang kesehatan untuk pengobatan penyakit (Angka \& Suhartono, 2000). Beberapa ahli menggunakan bulu babi sebagai salah satu organisme paling populer untuk mempelajari biologi reproduksi (Vacquier et al., 1995), embriologi (Davidson et al., 1998; Lee et al., 1999), toksikologi (Dinnel et al., 1989), regulasi gen (Davidson et al., 2002), dan biologi evolusi (Peterson et al., 2000).

Bulu babi tersebar di hampir semua zone lautan. Hewan dalam filum Echinodermata ini sangat beragam. Diketahui ada sekitar 800 spesies bulu babi di dunia. Di Perairan IndoMalaya (Perairan Indonesia, Malaysia, Filipina, sebagian wilayah Australia Utara) diketahui berjumlah sekitar 316 spesies (Clark \& Rowe, 1971). Khusus di Perairan Indonesia diketahui sekitar 84 jenis yang tergabung dalam 48 marga dan 21 suku (Aziz, 1987). Bulu babi tersebut berasal dari berbagai ordo, famili, genus, dan spesies.

Keragaman genetik bulu babi sangat tinggi. Hal ini dilihat dari Deoxyribo Nucleic Acid mitokondria (mtDNA) dan atau DNA inti (nDNA) antarfamili atau spesies bulu babi. Berdasarkan keragaman tersebut diketahui tidak ada dua organisme dari spesies sama yang benar-benar serupa, karena setiap spesies memiliki materi genetiknya sendiri-sendiri. Dalam istilah genetik, spesies adalah polimorfis.
Keragaman genetik dapat dipelajari dengan metode morfometrik, biokimia, dan metode molekuler. Metode morfometrik merupakan metode taksonomi tradisional. Metode ini digunakan untuk melukiskan variasi antara individu dan populasi (Mortensen, 1943; Clark \& Rowe, 1971; Jensen, 1974; Jensen, 1981). Metode ini menggunakan karakter morfologis dan meristik (dapat dihitung) sebagai rasio panjang standar atau panjang garpu. Karakter morfologi mempunyai keterbatasan untuk menggambarkan keragaman genetik intraspesifik karena umumnya poligenik dan ekspresi dapat dimodifikasi oleh lingkungan.

Elektroforesis gel dan penanda histokimia protein tertentu merupakan metode biokimia paling umum digunakan untuk mengukur variasi genetik dalam populasi alami. Metode ini relatif murah dan lebih mudah diinterpelasi karena menggunakan program komputer untuk analisis data. Kebanyakan survei keragaman genetik spesies laut telah menggunakan protein sebagai heterozigot rata-rata melebihi kebanyakan loci protein. Meskipun demikian karena gen-gen protein hanya mewakili sekitar $10 \%$ dari genomnya, maka hubungan antara heterozigosit dan kesegaran protein menjadi tidak jelas (Mitton \& Grant, 1984; Allendorf \& Leavy, 1986; Danzmann et al., 1989).

Metode biokimia lain adalah kariologikal. Metode ini dapat digunakan untuk menentukan variasi genetik, seperti sejumlah kromosom atau pita polimorfis. Meskipun demikian teknik tersebut sulit dibandingkan dengan teknik elektroforesis dan tekniknya menggunakan organisme hidup untuk preparasi kromosom. Hal ini mengurangi potensi penerapannya untuk kebanyakan spesies laut. 
Kemajuan biologi molekuler telah menyumbang teknik pengujian langsung variasi DNA. Diantaranya Restriction Fragment Length Polymorphisms (RFLP) sebagai salah satu alat atau metode pengukuran keragaman genetik molekuler. Polymerase Chain Reaction (reaksi berantai polimerase) merupakan metode molekuler lain yang dapat digunakan untuk melakukan screen variasi genetik dalam individu dan populasi. (Ogawa et al., 2000; Martin et al., 2001; Kitamura et al., 2002).

\section{Keragaman genetik bulu babi mtDNA}

mtDNA atau genom mitokondria adalah molekul rantai ganda sirkular yang berasal dari luar inti atau tepatnya dari organel mitokondria. mtDNA bulu babi mengkode gen sama dengan genom mitokondria vertebrata (Jacobs et al., 1988; Cantatore et al., 1989; De Giorgi et al., 1996). Meskipun demikian urutan dan distribusi gen di antara kedua rantai sangat berbeda. Perbedaan utama terletak di dalam pemisahan dua gen rRNA, kelompok 15 gen tRNA dan ukuran reduksi daerah nonkode utama (NCR= non-coding region) yaitu sekitar $130 \mathrm{pb}$ (Jacobs et al., 1989).

Genom mitokondria bulu babi memiliki gen yang mengkode 13 polipeptida, 2 rRNA dan 22 tRNA seperti pada mtDNA hewan lain. Genom mitokondria bulu babi terorganisir lebih ekonomis, informasi nonkode antara gen hampir seluruhnya tidak ada, beberapa kodon berhenti dihasilkan secara post-transkripsi dan urutan tRNA diselingi hanya antara minoritas gen struktural lain. mtDNA bulu babi juga menggunakan kode genetik berbeda, AAA untuk asparagin, ATA untuk isoleusin, TGA untuk triptofan dan AGN untuk serin serta memiliki pola tidak umum dari bias kodon. Urutan gen juga menunjukkan beberapa perbedaan dengan vertebrata. Gen-gen untuk rRNA besar (16S) dan subunit NADH dehidrogenase 4L (NDHL) posisinya berbeda (Jacobs, 1988).

Bulu babi dalam famili berbeda menunjukkan variasi mtDNA-nya. mtDNA bulu babi memiliki panjang total sekitar 15,7 kb (Fernandes-Silva et al., 2001). Panjang
mtDNA Strongylocentrotus purpuratus adalah 15.650 pb (Jacobs, 1988), Paracentrotus lividus adalah 15.697 nukleotida (Cantatore et al., 1989) dan mtDNA Arbacia lixula adalah 15,719 nukleotida (De Giorgi et al., 1996). Komposisi nukleotida mtDNA A. lixula berbeda dengan mtDNA $S$. purpuratus dan $P$. lividus. Salah satu contoh pada perbedaan tersebut adalah bias dalam penggunaan nukleotida $\mathrm{T}$ dan cenderung menghindari penggunaan nukleotida $\mathrm{C}$, dalam posisi kodon ketiga. Hal ini menunjukkan bahwa ketiga mtDNA bulu babi tersebut berkembang di bawah tekanan mutasi berbeda (De Giorgi et al., 1996).

Perbedaan mtDNA bulu babi dalam satu famili juga ditemukan. Hasil penelitian Lee (2003) menunjukkan bahwa secara genetik di dalam urutan mtDNA daerah 12srDNA-tRNA (gln) yang berasal dari tujuh spesies dalam famili Strongylocentrotid (S. intermedius, $S$. purpuratus, S. pallidus, S. droebachiensis, $H$. pulcherrimus, S. nudus, S. franciscanus, dan $P$. lividus) terdapat variasi yang cukup berarti.

\section{nDNA}

nDNA adalah molekul rantai ganda non sirkular yang berasal dari organel inti (nuclear) sel. nDNA bulu babi berukuran sekitar $800 \mathrm{mb}$. Genom ini terdiri atas 27.350 gen, memiliki rata-rata spacing gen $29.000 \mathrm{pb}$ dan frekuensi famili ulangan tengah $500-8.500$ elemen per genom (7,5\% dari DNA genom). Selain itu dalam nDNA bulu babi terdapat sekitar 39\% GC dan memiliki sekitar 25\% urutan berulang yang berisi unit elemen kompleks berbeda di setiap kisaran hingga sepuluh ribu per genom (Cameron et al., 2000).

nDNA bulu babi juga mempunyai organisasi urutan selingan pendek yang khas, seperti domain salinan tunggal yang disela oleh elemen ulang pendek (panjangnya beberapa ratus nukleotida) setiap pasang kilonukleotida. Ada juga beberapa kelompok domain ulang panjang termasuk ketiga dari semua panjang urutan ulang. Jadi umumnya elemen urutan ulang pendek. Rata-rata beberapa sisipan setiap $100 \mathrm{~kb}$ gen elemen dapat dipindahkan (transposable), biasanya sisa gen transkriptase balik. Selain itu genom inti bulu babi mengandung frekuensi ordinary dari 
mikrosatelit yang baik (Cameron et al., 2000; Davidson et al., 2002).

nDNA juga bervariasi antarfamili bahkan antarspesies. Seperti ditunjukkan dalam keanekaragaman identitas dan jarak genetik antara enam spesies bulu babi dari famili Echinometridae dalam Tabel 1.

Keenam spesies memiliki identitas dan jarak genetik berbeda satu dengan yang lain. Heterocentrotus mammillatus dan Colobocentrotus mertensii sangat berbeda secara genetik dari 4 spesies lain. Anthocidaris crassispina meskipun sangat dekat berhubungan dengan echinometra daripada dengan echinostrephus, identitas dan jarak genetiknya juga berbeda. Dua spesies yang sangat mirip secara morfologi yaitu $E$. aciculatus dan E. molaris sangat kecil perbedaannya secara genetik dari yang lain tetapi tetap memiliki identitas dan jarak genetik yang berbeda (Matsuoka \& Suzuki, 1989).

Keragaman genetik nDNA dalam satu spesies diperlihatkan pada jenis bulu babi $E$. mathaei. Bukti genetik menunjukkan perbedaan empat jenis bulu babi yang diklasifikasikan dalam spesies sama tersebut. Empat jenis bulu babi E. mathaei yang memiliki pola warna duri yang berbeda setelah dilakukan analisis elektroforesis dengan berbagai enzim tertentu diketahui merupakan empat jenis bulu babi yang berbeda, tipe A, B, $C$, dan tipe D. Keempatnya memiliki alel berbeda pada 7 loci genetik dalam nilai total 28 loci genetik. Hal ini jelas menunjukkan bahwa tidak ada aliran gen antara keempat jenis dan merupakan bukti kuat bahwa mereka secara reproduksi berbeda dan secara genetik merupakan spesies berbeda (Matsuoka \& Hatanaka, 1991).

Beberapa contoh yang disampaikan menunjukkan keragaman genetik bervariasi antarfamili dan juga dalam satu famili.

\section{Manfaat keragaman genetik}

Keragaman genetik bulu babi merupakan bidang penelitian yang menarik. Alasannya adalah: 1. setiap genom mahluk hidup memiliki ciri khas yang dapat menghasilkan informasi mekanistik yang berharga dalam berbagai bidang pengetahuan; 2 . pengetahuan filogenetik bulu babi posisinya relatif lebih dekat dengan semua deuterostoma lain (termasuk dengan manusia) dibandingkan dengan beberapa hewan lain; 3. bulu babi adalah target utama untuk investasi genomik karena organisme ini satu-satunya deusterostoma nonchordata yang bertindak sebagai model penelitian utama saat ini (Davidson \& Cameron, 2003).

Berdasarkan manfaat yang dimiliki bulu babi dan alasan di atas lembaga National Human Genome Research Institute menempatkan bulu babi sebagai salah satu organisme prioritas dalam penentuan urutan genom dalam proyek yang dilaksanakannya. Lembaga ini juga mendanai Proyek Genom Bulu Babi (Sea Urchin Genome Project) yang mulai dikerjakan tahun 2000 (Pennisi, 2002).

Selain hal tersebut keragaman genetik bulu babi dapat dimanfaatkan di antaranya untuk:

1. sumber gen, mencari gen unggul dalam hal pertumbuhan, tahan terhadap penyakit, kemampuan adaptasi yang tinggi, bentuk yang eksotis

2. seleksi gen spesifik, beberapa negara telah berhasil dalam melakukan seleksi jenis organisme tertentu dalam keseragaman ukuran dan kecepatan pertumbuhan

3. menentukan hubungan kekerabatan serta proses evolusi dan ekologi antar organisme termasuk dimanfaatkan untuk mempelajari taksonomi mahluk hidup

4. melakukan konstruksi ulang filogenetik dan menguji struktur populasi spesies mahluk hidup

5. identifikasi atau melukiskan stok populasi

6. merancang program peningkatan atau pengembangan genetik untuk sistem budi daya yang unggul

7. manipulasi lingkungan budidaya

8. mempelajari bagaimana jalur regulasi gen dan protein pertumbuhan dan perkembangan yang dapat digunakan untuk memahami biologi manusia merancang strategi konservasi dan meningkatkan pengembangan pemanfaatan sumber daya genetik untuk masa datang (Jacobs \& Grimes, 1986; Biermann et al., 2003; Davidson et al., 2002). 
Keragaman Genetik Bulu Babi

Tabel 1. Identitas genetik (diagonal atas) dan jarak genetik (diagonal bawah) antara enam spesies bulu babi dari famili Echinometridae

\begin{tabular}{clcccccc}
\hline \hline No & \multicolumn{1}{c}{ Spesies } & $\mathbf{1}$ & $\mathbf{2}$ & $\mathbf{3}$ & $\mathbf{4}$ & $\mathbf{5}$ & $\mathbf{6}$ \\
\hline \hline 1. & A. crassispina & - & 0.631 & 0.587 & 0.579 & 0.380 & 0.487 \\
2. & E. mathaei & 0.460 & - & 0.585 & 0.581 & 0.434 & 0.509 \\
3. & E. aciculatus & 0.533 & 0.536 & - & 0.963 & 0.390 & 0.426 \\
4. & E. molaris & 0.546 & 0.543 & 0.038 & - & 0.369 & 0.442 \\
5. & H. mammillatus & 0.968 & 0.835 & 0.942 & 0.997 & - & 0.476 \\
\hline 6. & C. mertensii & 0.719 & 0.675 & 0.853 & 0.816 & 0.742 & - \\
\hline \hline
\end{tabular}

Sumber: Matsuoka dan Suzuki, (1991)

\section{Kesimpulan}

Fakta mengenai keragaman genetik yang berasal dari nDNA dan mtDNA di antara spesies dan antarfamili memberikan gambaran tentang besarnya potensi keragaman genetik bulu babi. Keberagaman ini penting diantaranya untuk sumber dan seleksi gen, menentukan hubungan kekerabatan, menentukan proses evolusi dan ekologi serta untuk kepentingan konservasi. Pertanyaannya adalah apakah potensi ini telah kita manfaatkan?

\section{Daftar Pustaka}

Allendorf, F.W. and Leavy, R.F. 1986. Heterozygosity and Fitness in Natural Populations of Animals. In: Soule, M.E. (Eds.). Conservation Biology, pp. 57-76. Sinauer Associates, Massachusetts.

Angka, S.L. dan Suhartono, M.T. 2000. Bioteknologi Hasil Laut. Penerbit Pusat Kajian Sumberdaya Pesisir dan Lautan Institut Pertanian Bogor. Bogor.

Aziz, A. 1987. Makanan dan Cara Makan berbagai Jenis Bulu Babi. Oseanologi XII (4): 91-100.

Biermann, C.H., Bailey, D.K. and Stephen, R.P. 2003. Phylogeny and development of marine model species: Strongylocentrid sea urchins. Evolution \& Development 5 (4): 360-371.

Cameron, R.A., Mahairas, G., Rast, J.P., Pedro, M., Ted, R.B., Steven, S., James, C.W., Albert, J. P., Brian, T.L., Gregory, A.W., Charles, A.E., Hans, L., Roy, J.B., Eric, H.D. and Leroy, H. 2000. A sea urchin genome project. Sequence scan, virtual map, and additional resources. Proceedings of the National Academy of Sciences USA 97: 9514-9518.
Cantatore, P., Marina, R., Guglielmo, R., Maria, N.G. and Cecilia, S. 1989. The complete nucleotide sequence, gene organization, and genetic code of the mitochondrial genome of Paracentrotus lividus. J. of Biological Chemistry. 264 (19): 10965-10975.

Clark, A.M. and Rowe, F.W. 1971. Shallow Water IndoWest Pacific Echinoerms. Publication No. 690. Trusteas of the British Museum Natural History, London.

Danzmann, R.G., Ferguson, M.M. and Allendorf, F.W. 1989. Genetic Variability and Components of Fitness in Hatchery Strains of Rainbow Trout. J. of Fish Biology 35: 313-319.

Darsono, P. dan Sukarno, 1993. Beberapa Aspek Biologi Bulu Babi, Tripneustes gratilla (Linnaeus), di Nusa Dua - Bali. Oseanologi di Indonesia 26: Nusa D. 25.

Davidson, E.H., Cameron, R.A. and Ransick, A. 1998. Speciafication of cell fate in the sea urchin embryo: summary and some proposed mechanisms. Development 125: 3269-3290.

Davidson, E.H., Rast, J.P., Oliveri, P., Andrew, R., Cristina, C., Chiou-Hwa, Y., Takuya, M., Gabriele, A., Veronica, H., César, A.M., Ochan, O., Titus, C.B., Carolina, B.L., Pei, Y.L., Roger, R., Alistair, G.R., Zheng, J.P., Maria, J.S., Peter, J.C.C., Maria, I.A., Lee, R., Andrew, R.C., David, R.McClay, Leroy, H. and Hamid, B. 2002. A genomic regulatory network for development. Science 295: 1669-1678.

Davidson, E.H. and Cameron, R.A. 2003. Argument for Sequencing the Genome of the Sea Urchin Strongylocentrotus purpuratus.

De Giorgi, C., Martiradonna, A., Lanave, C. and Saccone, C. 1996. Complete sequence of the mitochondrial DNA in the sea urchin Arbacia lixula: conserved features of the echinoid mitochondrial genome. Mol Phylogenet Evol. 5(2): 323-32. 
Dinnel, P.A., Link, J.M., Stober, Q.J., Letoumeau and Roberts, W.E. 1989. Comparative M.W.sensitivity of sea urchin sperm bioassays to metals and pesticides. Arch. Environ. Contam. Toxicol. 18: 748-755.

Fernande-Silva, P., Polosa, P.L., Roberti, M., Barbara, D.P., Maria, N.G., Julio, M. and Palmiro, C. 2001. Sea Urchin mtDBP is a Two-faces Transcription Termination Factor with a Biased Polarity Depending on the RNA Polymerase, Nucleic Acid Research 29 (22): 4736-4743.

Jacobs, H.T., David, J.E., Veerabhadracharya, B.M. and Andrew, F. 1988. Nucleotide Sequence and Gene Regulation of Sea Urchin Mitochondria DNA. J. of Molecular Biology 202 (2): 185217.

Jacobs, H.T. and Grimes, B. 1986. Complete Nucleotide Sequences of the Nuclear Pseudogenes for Cytochrome Oxidase Subunit I and the Large Mitochondrial Ribosomal RNA in the Sea Urchin Strongylocentrotus purpuratus. J. Mol. Biol. 187: 509-527.

Jacobs, H.T., Herbert, E.R. and Rankine, J. 1989. Sea Urchin Egg Mitochondrial DNA contains a short displacement loop (D-loop) in the replication origin region. Nucleic Acids Res. 17: 8949-8965.

Jensen, M. 1974. The Strongylocentrotidae (Echinoidea), a Morphologic and Systematic Study. Sarsia 57: 113-148.

Jensen, M. 1981. Morphology and Classification of Euchinoidea Bronn, 1860-a Cladistic Analysis. Vidensk. Meddr. Dansk Naturh. Foren. 143: 7 99.

Kitamura, K., Nishimura, Y.m Kubotera, N., Higuchi, Y. and Yamaguchi, M. 2002. Transient Activation of the Microl Homeobox Gene Family in the Sea Urchin (Hemicentrotus pulcherrimus) Micromere. Dev. Genes Evol. 212: 1-10.

Lang, C. and Schroeter, S.C. 1976. Change in sea urchin populations after the destruction of kelp beds. Mar. Biol. 36: 321-326

Lawrence, J.M. 1975. On the relationship between marine plants and sea urchins. Oceanogr. Mar. Biol. Ann. Rev. 13: 213-286.
Lee, Y-H., Huang, G.M., Cameron, R.A., Graham, G., Davidson, E.H., Hood, L. and Britten, R.J. 1999. EST analysis of gene expression in early cleavage-stage sea urchin embryos. Development 126: 3857-3867.

Lee, Y-H. 2003. Molecular Phylogenies and Divergende Times of Sea Urchin Species of Strongylocentrotidae, Echinoidea. Mol. Biol. Evol. 20 (8): 1211-1221.

Matsuoka, N. and Hatanaka, T. 1991. Molecular evidence for the existence of four sibling species within the sea-urchin, Echinometra mathaei in Japanese waters and their evolutionary relationships. Zoological Science 6: 589-598.

Matsuoka, N. and Suzuki, H. 1989. Electrophoretic study on the pphylogenetic relationships among six species of sea-urchins of the family echinometridae found in the Japanese Waters. Zoological Science 8: 121-133.

Martin, E.L., Consales, D., Davidson, E.H. and Amone, M.I. 2001. Evidence for a Mesoderma Embryonic Regulator of the Sea Urchin Cylla Gene. Dev. Biol. 236: 46-63

Mitton, J.B. and Grant, M.C. 1984. Associations among Protein Heterozygosity Growth Rate, and Developmental Homeostatis. Annual Review in Ecology and Systematics 16: 479-499.

Mortensen, T. 1943. A Monograph of the Echinoidea. C.A. Reitzel, Copenhagen.

Nontji, A. 2002. Laut Nusantara. Cetakan Ketiga. Penerbit Djambatan Jakarta

Ogawa, M., Akasaka, K., Mitsunaga Nakatsubo, K. and Shimada, H. 2000. Sox Regulates Transcription of the Sea Urchin Arylsulfatase Gene. Dev. Growth Differ 42: 429-435.

Pennisi, E. 2002. Chimps and fungi make genome "Top Six." Science 296: 1589-1591.

Peterson, K.J., Cameron, R.A. and Davidson, E.H. 2000. Bilaterian origins: significance of new experimental observations. Dev. Biol. 219: 117.

Vacquier, V.D., Swanson, W.J. and Hellberg, M.E. 1995. What have we learnd about sea urchin sperm bindin? Dev. Growth Differ 27: 1-10. 